\title{
When The Phantom Became an Anticolonialist: Socialist Ideology, Swedish Exceptionalism, and the Embodiment of Foreign Policy
}

Robert Aman

The self-archived postprint version of this journal article is available at Linköping University Institutional Repository (DiVA):

http:/ / urn.kb.se/ resolve?urn=urn:nbn:se:liu:diva-146259

N.B.: When citing this work, cite the original publication.

This is an electronic version of an article published in:

Aman, R., (2018), When The Phantom Became an Anticolonialist: Socialist Ideology, Swedish

Exceptionalism, and the Embodiment of Foreign Policy, J ournal of Graphic Novels and Comics, , 1-18. https:// doi.org/ 10.1080/ 21504857.2017.1403334

Original publication available at:

https:/ / doi.org/ 10.1080/21504857.2017.1403334

Copyright: Taylor \& Francis (Routledge) (SSH Titles)

http:// www.routledge.com/ 


\title{
When The Phantom Became an Anticolonialist: Socialist Ideology, Swedish Exceptionalism, and the Embodiment of Foreign Policy
}

\section{Robert Aman}

\begin{abstract}
The Phantom, an American comic about a superhero of British heritage set in a fictional African country, is held in highest esteem elsewhere, regarded as a national institution in Australia, New Zealand and much of Scandinavia. Since the early 1960s, officially licensed scripts have been produced by the Swedish-based scriptwriters of 'Team Fantomen' who today remain the major suppliers of adventures to the Phantom comics around the world. This essay suggests that this shift in the scripts' geographical origin also altered the politics of the comic: in the hands of Team Fantomen, the masked hero is instilled with political doctrines reflected in Swedish foreign policy during the late 1960s and early 1970s. This ideological shift means that the masked hero moves away from the role of colonialist fantasy prevalent in the American scripts to become a supporter of decolonization, social justice, and equality. The Phantom becomes an avatar of democratic socialist ideology, the episodes offering a direct commentary on Sweden's perception of its own role in the world as a leading proponent of international solidarity.
\end{abstract}

\section{Introduction}

The brainchild of American writer Lee Falk, The Phantom made its inaugural entrance on the comics scene as a daily strip in 1936. Veiled in mystery, the Phantom is seemingly immortal, presiding over a hidden stretch of jungle located in a fictional country named Bangalla on the African continent, residing in the Skull Cave which houses the crypts of his ancestors, along with the 'Phantom Chronicles', a library containing the hand-written accounts of his forefathers' exploits. Otherwise known as the 'Ghost Who Walks', the current Phantom, Kit Walker, is in fact not a spectre but the twenty-first generation of Phantoms, descended from a shipwrecked English nobleman, Sir Christopher Walker, ${ }^{1}$ who is the lone survivor of a vicious pirate attack on a merchant ship in 1525. Washed up on a remote shore on the African coast, the last thing he remembers before falling into the water is witnessing the killing of his father. He later discovers the body of his father's murderer and swears a solemn oath on his skull 'to devote [his] life to the destruction of all forms of piracy, greed and cruelty'; a task to be inherited by each first-born son. A dynasty of vigilantes is born.

The Phantom appears in more than 500 newspapers, translated into 40 languages with 60 million readers daily. ${ }^{2}$ Although it is an American literary creation with a protagonist of British heritage set in an exotic African jungle, the popularity of the comic is greatest elsewhere. In an in memoriam for inventor Lee Falk after his death in 1999, the Guardian mentions that The Phantom has become 'a national

\footnotetext{
${ }^{1}$ The first Phantom is also named Christopher Standish in certain versions of the story.

2 These numbers are from the Los Angeles Times, March 16, 1999. The Guardian, 20 March, 1999, cites even more generous numbers, reporting that the Phantom currently appears in over 600 newspapers in nearly 40 countries in 15 languages.
} 
institution in Australia, New Zealand and much of Scandinavia.' Indeed, ever since its first appearance in 1950, The Phantom has been one of the most popular comic books in Sweden. ${ }^{3}$ Anyone who, like myself, grew up in Sweden in the 1990s will vividly remember, besides reading the actual comic fortnightly, rehydrating with Phantom soda, eating the masked hero's own sweets, or even visiting him in person at his own theme park, Fantomenland ('Phantom Land'), in the city of Eskilstuna. A recent anthology devoted to the crime fighter is symptomatic of the Phantom series' popularity in the Swedish context, which is unrivalled by any other superhero comic: it allows various celebrities and other prominent figures, including a former Prime Minister, to discuss what the Phantom means to them while the hero himself poses in front of a Swedish flag on the cover and is referred to in the title as a 'blue-yellow hero'.

A clue to The Phantom's popularity at the particular moment when the series made its first appearance can be found in its transformation of Africa into a stage on which the heroic European protagonist acts out his personal adventure narrative in the presence of alien people, wild animals and exotic scenery; a scenario which is closer to a rule than an exception in twentieth-century Western literary production. And comic books are no exception: the period stretching from the 1930s to the end of the Second World War saw a dramatic increase in comics set in a jungle environment from Akim and Bomba the Jungle Boy to Cave Girl and Ka-Zar the Savage - that all share the trope of white European authority over native people (Costello 2009). Part of Falk's genius, Kai Friese (1999) contends, was to weave prominent examples of the colonial canon into the storyline: the Phantom starts out as a Robinson Crusoe alone in unfamiliar territory, shares characteristics with Mowgli from the Jungle Book and mirrors Joseph Conrad's Mr Kurtz, albeit with an opposing agenda, as an obsessed white man on a civilizing mission on the 'dark continent'.

Yet this does not necessarily explain the enduring fascination with the Phantom and the series' remarkable sustainability in Sweden with an uninterrupted biweekly print run still on-going after more than 60 years. There is a seemingly unresolvable contradiction between a series that has been labelled 'a Colonialist fantasy about Black tribal peoples who live in peace thanks to the guidance of a line of wise and powerful white men' (Peterson 2009) and its continued success in a country that, according to academic commentators, during the 1960s and 1970s developed into the most progressive antifascist and antiracist nation in the West (Hübinette and Lundström 2011). For instance, the series to which The Phantom bears the greatest resemblance, Edgar Rice Burroughs' Tarzan - Falk once even referred to his own creation as 'Tarzan with a college degree' - was already experiencing a steady decline in US sales figures by the time the comic had several short-lived runs with different publishers in Sweden in the 1960s. By contrast, the Phantom series enjoyed its peak years of Swedish sales during the 1970s.

Academic commentators have sought to explain Sweden's long lasting love affair with the masked crusader as, in large part, a consequence of some of the most active contributors to the series in recent decades having been the Swedish-based creators known as 'Team Fantomen'. ${ }^{4}$ Since 1963 Team Fantomen has produced

\footnotetext{
${ }^{3}$ The Phantom had made its first appearance as a comic strip ten years earlier in 1940 in the pages of Veckorevyn. The series' longest run is with the daily broadsheet Svenska Dagbladet, in which it has never ceased to appear since its debut in 1942.

${ }^{4}$ These include, among others, editor and writer Ulf Granberg, writers Janne Lundström, Magnus Knutsson, Lennart Moberg, and Claes Reimerthi, and artists Kari Leppänen, Hans Lindahl and Jaime Vallvé.
} 
officially licensed episodes and remains today the major supplier of adventures to the Phantom comics around the world. According to David Gudmudsson, this gave the editorial team and scriptwriters leverage to tailor plots in accordance with the interests of their implied local readership. Gudmundsson $(2015,21)$ specifically mentions the increased focus on historical adventures as characteristic of Team Fantomen, suggesting that '[a] consciously applied commercial use of history has contributed to the successes of Fantomen in recent decades.' Most interestingly, when

Gudmundsson rephrases the argument as part of his conclusion, employing the theoretical framework of cultural memory, he distinguishes the political purposes of cultural memory from commercial ones: 'there is a difference, I would argue, in using an historical theme with ideological and political purposes, or with the purpose of presenting an exciting character for commercial uses.' Based on the analysis pursued, he draws the conclusion that 'the use of history in comics such as Fantomen is primarily commercial - it appeals to a great interest in history in modern society, which helps sell more copies of the comic' (Gudmundsson, 2015, 21).

Such an argument not only detaches cultural memory from its social and political underpinnings, it also overlooks the ways in which comic books are, in Jesse Moore's $(2003,263)$ words, 'purveyors of ideology'. ${ }^{5}$ For all the important merits of Gudmundsson's work, the argument advanced in this essay is quite the opposite: what I will demonstrate is that the Swedish scriptwriters endow the Phantom with new political meaning, and that this is a major reason for the popularity of the character. Or put another way, that a full comprehension of The Phantom's popularity during the comic's peak years in the 1970s requires an understanding of the ideological climate in which the comic circulated, as the story arc dramatizes social and political issues in such a way that the masked hero seamlessly embodies the dominant ideology of the time.

The founding of Team Fantomen coincided with an altered Swedish political landscape that placed an increased emphasis on so-called Third World issues in general and on Africa in particular - the institutionalization of foreign aid, the founding of various African solidarity movements, the state-funded construction of folk high schools on the African continent, to mention a few of the many salient initiatives. In response to growing domestic pressure, and to its own inclinations, the Social Democratic government began contributing generously to movements in southern Africa fighting against the injustices of colonial or postcolonial rule. Public engagement with the plight of black people in different parts of Africa went so far that the countries particularly targeted by the various governmental aid programmes became household names in Sweden, and behind the word was the image of people struggling for racial equality and independence against their white overlords (Gleijeses 2005; Sellström 1999). In an expression of the government's ideological compass at the time, future Prime Minister Olof Palme, in a speech from 1965, made it abundantly clear that to be a socialist implies solidarity with the so-called Third World. As a member of the Agency for International Assistance and in charge of inquiries into assistance to developing countries, Palme $(2006,234)$ states that 'The basic moral values of democratic socialism oblige us to stand with the oppressed against the oppressors, on the miserable and poor people's side against their exploiters and masters.'

As has been noted in relation to the publishers DC Comics and Marvel during the Cold War, superhero stories were consciously set in a world beset by Communist

\footnotetext{
${ }^{5}$ For a more detailed account of ideology in comics see Barker (1989) or MacAllister et. al. (2001).
} 
foes in an attempt to define an American identity (e.g. Costello 2009; Dittmer 2013; York and York 2012). What I will argue here is that a similar yet different phenomenon occurs in the Swedish licenced scripts: The Phantom constitutes a system of signs that reflect, comment upon and interact with Swedish foreign policy, as the Ghost Who Walks is transformed into a supporter of decolonization, social justice, and equality. The Phantom is, in fact, an avatar of democratic socialist ideology; the episodes offer a direct commentary on Sweden's perception of its own role in the world as a leading proponent of international solidarity.

Inspired by Susan Suleiman (1993), my use of 'ideology' in this essay denotes the ways in which a work of fiction seeks to persuade the implied reader of the 'correctness' of a particular way of interpreting the world. Granted, any piece of art or literature can in a broad sense be considered ideological. After all there is, as Roland Barthes (1977) often remarked, no discourse wholly free from ideology. Yet, the definition employed here carries a narrower meaning as ideology refers explicitly to a certain system of ideas perpetuated through the vehicle of fiction. Suleiman (1993) refers to this form of literature as a roman à thèse; that is, a work of fiction that is didactic in its intent, seeking to manifest the validity of a political, philosophical or religious doctrine. The rhetoric of the roman à thèse can be analysed through its reliance on a 'redundant discourse,' where redundancy is defined as a 'surplus of communication' (Suleiman 1993, 55). The particular function of a redundant discourse is, paradoxically, to limit the potential for a plurality of readings. Instead, the roman à thèse seeks to increase the probability of a correct reception of the message by an excessive signalling of that message's meaning. As such, and in order to reduce ambiguity, the roman à thèse thrives on ideological polarization, which becomes both a fundamental theme and an organizing principle (Suleiman 1993).

There is, however, a notable difference between Suleiman's errand and my own: where Suleiman inquires into a corpus of prominent French works - by André Malraux, Paul Nizan, Jean-Paul Sartre, to name a few - from the first half of the last century, this essay scrutinizes a medium lower down on the cultural food chain targeting a substantially broader and more popular readership. Furthermore, the combination of images and text gives an additional dimension to our understanding of the roman à thèse as the message the comic seeks to convey is as ingrained into the images as the text. In short, it would perhaps be more apt to speak here of a comic $\grave{a}$ thèse.

\section{From Colonial India to Postcolonial Africa}

A subtle cartographical change is of great importance to the storyline of The Phantom. While Lee Falk was always vague about the location of Bangalla ${ }^{6}$ to the point of contradiction - often alluding to its fictional nature ('The Phantom lives in neither Asia or Africa, but in the jungle. My own jungle') or its partial resemblance to existing territories ('It's located partly in Asia and partly in Africa') - the Swedish produced scripts are characterized by geographical specificity. ${ }^{7}$ In the stories of Team

\footnotetext{
${ }^{6}$ In many versions of The Phantom, including the Scandinavian comic books, the country is called 'Bengali' which was the name Lee Falk used in the first decades, when the country was placed closer to India. As Bengali was confirmed as being in Africa during the 1960s, Falk renamed the country to Bangalla in the 1970s.

${ }^{7}$ This interview with Lee Falk, which is one of many where similar answers were given, was given in 1964 to Alain Resnais and published in Lee Falk Memorial Bengali Explorers Club. Scandinavian Chapter, Lee Falk: Story teller, GML, Stockholm, 2011.
} 
Fantomen, Bangalla is a former British colony located on the west coast of Africa which has recently gained its independence. Fixing Bangalla's spot on the world map allowed the Swedish writers to add a layer of historical realism to the stories, as exemplified by the opening caption to the story 'The False Commandant' from 7/1972:

The democracy in Bangalla is fragile and weak as in all developing countries! It is constantly under threat from ancient divisions between the country's various tribes, from military figures that want to impose a dictatorship, and from the former white colonial masters who still remain powerful in the country! ${ }^{8}$

In relating Bangalla to other developing countries, suggesting degrees of generalizability and similarity between postcolonial nations that have made the march to independence, the comic links the backdrop of the storyline to a world political stage. In contrast to Falk who often structured his stories in conformity to stereotypical Western exoticist paradigms ('primitive culture', 'unbound nature', 'noble savages'), captions in the Swedish scripts attempt to present a more or less transparent window into the world of a post-independence African state. As noted in the caption above, Bangalla confronts the same problems as other former colonies: the potential turmoil of internal ethnic conflicts, constant threats of a coup d'état, and continuing embeddedness in a relationship with the former colonial authority. This is not to suggest that the plots have pretensions to be anything other than superhero stories. Nor can it be ignored that representations of African states as under constant threat of implosion into undifferentiated chaos are equally as ingrained into colonial discourse as exotic myths in which the continent and its people are depicted as primitive, mystical, and traditional (Mbembe 2001). Instead, I argue that the move away from Falk's emphasis on Bangalla's apparent fictional nature to Team Fantomen's inscription of the Phantom Country as part of postcolonial Africa serves the ideological interests of the text, enabling subplots involving racism, slavery and the pillaging of Africa's resources that speak directly to a vivid debate about the reasons for Swedish foreign aid. This combination of realism and didacticism is characteristic of the roman à thèse, in which fictional representation seeks to align itself with a historical reality in order to persuade the reader of the righteousness of the message conveyed (Suleiman 1993).

The change in the politics of the comics was a conscious decision. Writing about his time with Team Fantomen during the 1970s, Magnus Knutsson (2003) explains how The Phantom was initially heavily criticized in Sweden where the educational section of the labour movement, the Workers' Educational Association (ABF), had pronounced it 'fascist' in its journal, and the Göteborgs-Tidningen newspaper initiated a debate on colonialist tropes in the comic. According to Knutsson, this fuelled the team's desire to 'modernize' the stories, suggesting that this was done by imbuing the Phantom with a resilient social consciousness and producing scripts that began to address prevalent structural injustices in contemporary Africa. And there was no greater injustice, Knutsson adds, than the ways in which a white ruling class oppressed the black population.

A prominent example of this political turn is episode 16/1971, 'The Secret of the Plantation'. ${ }^{9}$ Passing through a flourishing valley, the Phantom wonders aloud why this part of the country has escaped governmental interference ('The large land

\footnotetext{
${ }^{8}$ Fantomen, 7/1972, script: Janne Lundström, art: Bertil Wilhelmsson.

${ }^{9}$ Fantomen, 16/1971, script: Janne Lundström, art: Bertil Wilhelmsson.
} 
reform that was conducted after Bangalla's independence doesn't include the Stevens Plantation. Very strange...') before being interrupted by the sound of blazing guns. Sprinting towards the gunfire, the Phantom discovers a dozen uniformed white guards beating an elderly black man, accusing him of trespassing on private property. After the Phantom rescues him, the old man, Mbebo, gives him a history lesson in return ('Our people lived here and cultivated the land in the Stevens' valley long before the whites conquered Bangalla. Then the soldiers came and took the land and our people became slaves under the Stevens family'). Continuing his story, Mbebo describes how Bangalla's independence and the land reform of President Lamanda Luaga - a close confidant of the Phantom - had a profound impact across the nation but did not include the Stevens' valley. This, Mbebo explains, is due to the owners' influential status: 'With the help of money and power they are able to oppose Bangalla's new government.'

As Mbebo educates the Phantom on a history of oppression, the panels show images of slaves performing the tedious work in the fields as well as offering glimpses into what happened to anyone who dared to defy the overlords, as a woman in chains screams out her pain while being whipped by a guard. In explaining the ways in which colonialism changed the relations of production ('The white instilled laws that forced us to work without payment') with a focus on racial exploitation ('If we spoke back, we got whipped - both men and women'), the panels offer a window into how race classification and control of labour complemented each other, resulting in the reduction of colonized people to unpaid labour forces at the service of white owners (Hardt and Negri 2000).

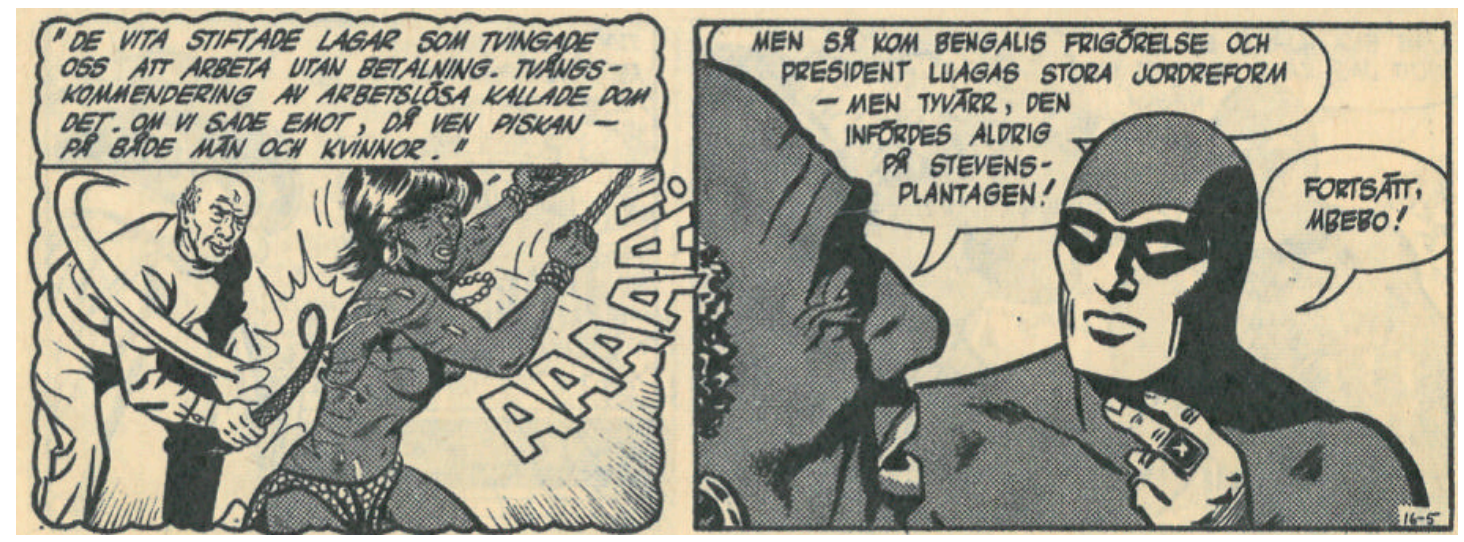

Mbebo teaches the Phantom about racial exploitation in Bangalla prior to the country gained independence. (C) King Features Syndicate Inc. / Distr. Bulls

The story sparks fury in the Ghost Who Walks. Enraged, he confronts the Minister of Agriculture who admits that the government is afraid to offend the Stevens family, as 'they own the copper company and have important foreign business relations that can stop our exports.' The Minister pauses before adding that this export is fundamental to the country's survival: 'without it Bangalla can't exist as a free nation.' Dressed as Mr Walker, his alias when leaving the jungle, wearing his customary sunglasses, hat and trench coat, the Phantom instructs the Minister that Bangalla is going to buy back the land from the Stevens family. Unaware of the Phantom's vast treasure trove in the back of his Skull Cave, the Minister finds himself in a state of shock as the mysterious stranger informs him that the necessary financial means will be delivered to his office. 'The plantation should be owned collectively,' the Phantom affirms, 'by the former slaves.' Several pages and violent confrontations later, the landlord agrees to sell the plantation back to Bangalla for a fraction of its value. 
The storyline draws its rhetorical strength from its eschewal of a gradual unfolding of events, instead moving straight to its predetermined conclusion. The reader is from the outset placed in the position of someone who shares the hero's values. In this particular case, the question is never whether the Phantom - and by extension we the readers - should sympathize with the black slaves or the white landlords, with African labour or European capital, with the colonized or the colonizers. The Phantom, like the implied reader, starts the story as a possessor of the 'right' values and is throughout fighting in their name. Suleiman $(1993,143)$ refers to this strategy, central to the roman à thèse, as 'persuasion by cooperation': the reader and the hero find themselves structurally - that is, necessarily - from the start on the 'right' side of the dividing line between the binaries of 'good' and 'evil'. In drawing a direct connection between the villain of the story, the landowning Stevens family, and the practice of reducing human lives to commodity and cargo, the storyline ensures that only a 'perverse' reader would favour a triumph of the villain over the hero (Suleiman 1993).

As is made abundantly clear by the story arc, the 'triumph' of the hero in this context implies that ownership of the land is transferred back to the people who cultivated it before European presence; the land should be, as verbalized by the Phantom, owned collectively by the former slaves. By inscribing the plot into a historical context which feeds directly into a contemporary public debate on decolonization which was as lively in Sweden (e.g. Sellström 1999) as elsewhere in Europe (e.g. Chamberlain 1999), the comic also encourages the reader's 'referential illusions,' to borrow again from Barthes (1973), by trying to break down the barrier between fiction and life. In a manner akin to the Phantom's faith in the sovereign state as the most effective way to bring about social justice, the Swedish government, in foreign policies that became gradually more ideologically coloured during the 1970s (Lödén 1999), advocated its own welfare state as a model for other countries, especially those in the Third World, to emulate (Nilsson 1991).

That the political climate in Sweden impacted the plots of The Phantom is confirmed by the editor of the comic, who regularly corresponded with readers in special members pages. Issue 3/1975 contains a letter from a reader describing himself as a devoted adult fan who praises the magazine for its 'ethical stance' as The Phantom has 'adapted to the fact that white, Western values have shown themselves to be fragile and doomed.' In his response to the letter, iconic editor Ulf Granberg adds that The Phantom's ability to keep up with the times is a characteristic 'that emerges with particular salience in the episodes that we [Team Fantomen] produce ourselves, both in writing and drawing.' As a concluding remark, Granberg informs his correspondent that the values instilled in The Phantom 'become in any case quite Swedish in this originally American series.' And to be 'Swedish' implied at this point in time to sympathize with the right to self-determination of the former colonies. Addressing this question in a widely discussed article from 1967, Palme $(2006,51)$ went so far as to suggest that a different stance would be impossible as 'the task is as far as possible to seek to liberate people from the dictatorship of social and economic relations.' In short, the Phantom's position on ethics overlaps with that of Sweden's foreign policy.

However, the above does not imply that the Swedish government's expressed solidarity with liberation movements in the so-called Third World was an implicit support for those acts of violence that Frantz Fanon (1966) famously deemed inescapable in the process of decolonization. On the contrary, the Social Democratic Party, in general, and Palme, in particular, were strong advocates of democratic 
reformism as a cautious path towards development and independence in former colonies (Fredriksson 2006). The Phantom's mindset is no different. When he seeks a resolution to the quarrel with the Stevens family, although he wishes to transform private property into a public asset, confiscation or other forms of force are never explored. While Mbebo's story makes it clear that the occupation of land in Africa was a form of robbery ('they took the land'), the Phantom never disputes the legality of private property - not even in this particular case where the accumulated wealth of the villains can be directly traced to the conquering of land and the countless hours extracted from forced labour.

In his seminal essay on Superman, Umberto Eco (1972) criticizes the Man of Steel for being a protector of capitalism as he only defeats villains that attempt to seize private property, without ever engaging in political or social struggles. Sharing both commonalities and differences with such an assessment of Superman's exploits, the Phantom embeds himself in political and social conflicts, firmly positioned on the workers', and their enslaved ancestors', side in the conflict, while never disputing capitalism as an economic system by arguing in favour of the abolishment of individual ownership. In short, respect for the legality of private property is privileged over the colonial wound; democratic reformism is favoured over state confiscation of private property. A possible reason for this is the dominance of the Social Democratic Party and its vocal anticommunism during the Cold War (Linderborg 2001), which at the same time meant that there were plausible marketing reasons for The Phantom not to allude to ideological cornerstones of the Soviet Union in critiques of extremist corporate capitalism and imperialist practices. Instead the triumph of the Phantom and by extension the reader - comes through his ability, within the bounds of the law, to make the Stevens family dramatically drop their asking price for the land their ancestors once acquired as part of colonial expansion.

\section{Against Capital, Towards Socialism}

The Phantom's political doctrine comes to the fore in another issue, 'The Trade War' $(3 / 1973),{ }^{10}$ which is a fictional foray into a postcolonial debate on debt and dependency. The arc begins with a peasant, Toro, informing his co-workers that he needs to buy a new spade as a thought bubble give away his suspicion that they are being duped ('I don't like the Whites in the store. Everything is more expensive every time one goes there') before admitting the reason for his lack of certainty ('I wish that I knew how to read and count'). Far from any urban areas, there is only one wholesale store in the entire region, which means that the unscrupulous white owner can raise the prices on the commodities to unaffordable levels.

In order to purchase the necessary equipment to perform their labour, the black worker sees no other option than to accept the proposed offer to hand over a part of the harvest as compensation. The panel shows a puzzled Toro struggling with the mathematics ('Trying in vain to get an idea of what tenths, fifths and percentages mean...') before signing the debenture with the owner laughing behind his back ('The idiot doesn't know that he has already transferred the rights to twelve tenths of his harvest to us'). When armed men arrive at the plantation demanding the harvest, the peasants realize that they have been tricked and are up to their ears in liabilities. In this moment of clarity, the workers start planning a violent revenge in order to take back what they have worked for.

${ }^{10}$ Fantomen, 3/1973, script: Janne Lundström, art: Bertil Wilhelmsson. 
Before a war breaks out, the Phantom arrives on the scene where he is briefed about the situation by the enraged work force ('We'll never get out of debt!'). What is interesting in this story arc is not the typical action packed way in which the Phantom goes about resolving the conflict with the villains, but the measures he takes to ensure that a similar situation will not arise again. Calling upon his friend, Trader Joe, to help the workers set up their own store, the Phantom informs them that 'He [Trader Joe] will also teach you what is meant by co-operative society, co-ownership and profit distribution!'. After being taught the ideas underpinning a co-operative society over supper ('So we're all co-owners and the profit is spent on the purchase of new goods?'), the caption states that it does not take long before the workers' co-owned store blossoms.

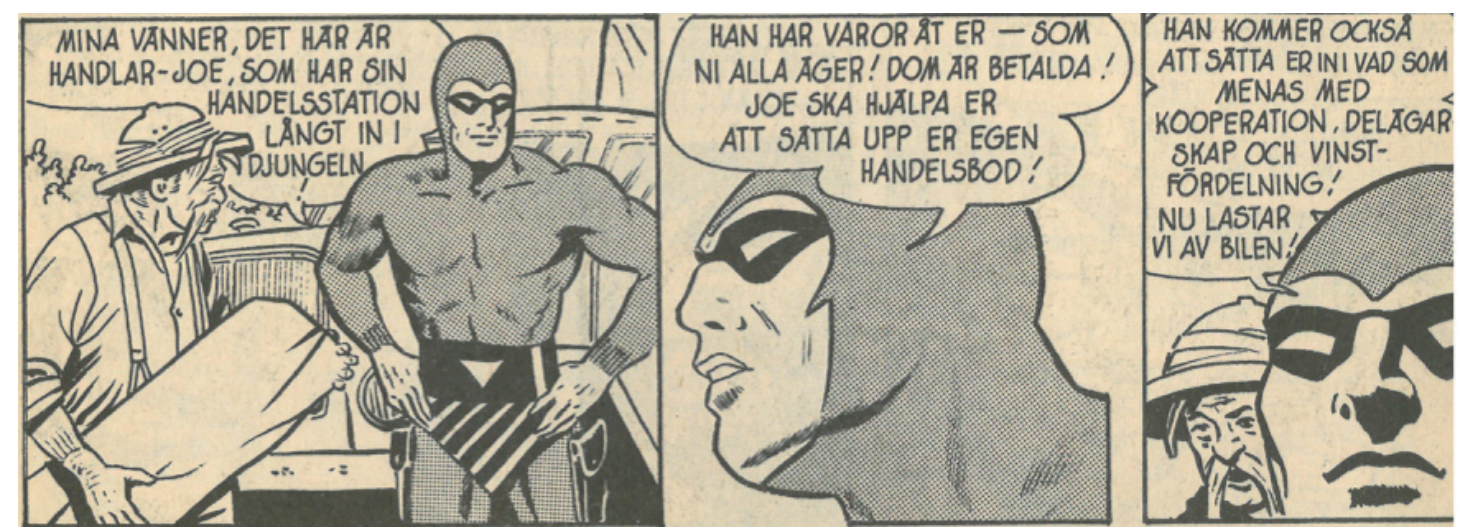

The Phantom introduces Trader Joe and informs the peasants that the old merchant will teach them the logics of a co-operative society and profit distribution. (C) King Features Syndicate Inc. / Distr. Bulls

The story reads allegorically: the comic hit newsstands around Sweden at a time when a paradigm shift had occurred in the understanding of the causes of underdevelopment. Neoclassical economic theories of economic growth, usually called 'trickle-down' economics, which had dominated the post-war discussion of development, were repudiated by neo-Marxist inspired theories of 'dependency'. Crudely put, the recipe for development was no longer necessarily based on a simplified view of all nations needing to emulate the growth patterns historically followed by the richest countries (Wallerstein 1974). Instead dependency theorists emphasize a causal connection between colonialism and underdevelopment. In possibly the most influential work of this school of thought, How Europe Underdeveloped Africa, leading proponent Walter Rodney (1972) argues that underdevelopment is the direct consequence of Africa's position as a cornerstone of the global capitalist system under colonialism, where the economic surplus that the continent produced was systematically exported to enrich the imperial centres. Hence, the development of Europe can be viewed as part of the same dialectical processes that underdeveloped Africa. Consequently, development and underdevelopment are two sides of the same coin - developed nations are actively underdeveloping Third World countries as a result of the systems of interaction between them. In addition to gaining widespread recognition in academic circles, these ideas acquired such influence that, in the case of Sweden, they were employed as an explanatory model for underdevelopment in Africa in school textbooks (Palmberg 1987).

Dependency theory frames the subplot of this Phantom adventure; the story offers a pedagogical illustration of dependency as a continuation of colonialism by demonstrating the contemporary roles of many former colonies within the capitalist system as agrarian economies specializing in exports in return for the importation of 
manufactured goods from the developed industrial world (Hobsbawm 2011). In a scheme where the main characters of the story come to embody their respective positions in the capitalist system, the black labourers (representing the underdeveloped world) find themselves in a position where they have no other alternative than to consume overpriced tools and instruments supplied by the white merchants (representing the developed world). The store itself stands in for the world market, illustrating the hierarchical relationship between 'core' and 'periphery', Europe and Africa, industrialists and agrarians, in which the peasants have no other means to pay than with their harvest, or indebting themselves through credit. Furthermore, what the plot reveals is that political decolonization by itself hardly changed the economic relations between many postcolonial states and their former metropolitan countries. Although considered as nominally sovereign states, they continue to be part of an imperial economy subordinated to a foreign power, reduced to supplying raw materials.

For these very reasons, proponents of dependency theory were stern critics of development aid - especially those measures focusing on export credit guarantees which most European nations, including Sweden, offered targeted countries suggesting that they veiled imperial ambitions in order to maintain former colonies in a state of dependency. In the case of Sweden, the impact of dependency theory, according to Bertil Odén (2013), went so far as to alter the development aid policy: instead of the focus on modernization through economic growth, investments, and trade that had dominated the first proposition from 1962 (1962:100), the next one in 1968 (1968:101) outlined a new goal of contributing to the economic independence of those countries that had recently gained their political liberation.

Secondly, the lack of literacy among the workers makes the case for the centrality of education to Swedish foreign aid during the 1970s. The objectives for Swedish development cooperation, formulated in 1962, state that the aim is to improve the living standards of poor people around the globe. This gave rise to a particular focus on supporting education in sub-Saharan Africa through literacy campaigns, aid to the printing and distribution of textbooks, and the construction of schools in the countryside (Linde 2000). Just as the Phantom ensures that the adult peasants receive basic training in reading and counting, a substantial part of Swedish development aid targeted mature learners with a particular focus on literacy. In Tanzania alone, over 50 folk high schools were set up with economic as well as educational and consultative support from Sweden (Nordvall and Dahlstedt 2011). ${ }^{11}$ Seen from this perspective, the story legitimizes Swedish foreign aid by pointing out its relevance: the implied reader is assured that these educational efforts would have prevented the African peasants from being stripped of their hard earned harvest and acquiring a heap of debt at the hands of deceitful exploiters - or will do so in the future.

Returning to the Phantom, the Ghost Who Walks does not speak up about what he considers to be 'right' or 'wrong' in a given situation, but shows it through his actions; actions that in turn, in line with the conventions of the roman à thèse, validate the political message the narrative seeks to convey. His formula for

\footnotetext{
${ }^{11}$ Historically in Sweden, and even more so in their home country of Denmark, folk high schools have been an alternative educational pathway for groups who have not gained access to other established educational institutions such as universities. In contrast to many other forms of formal schooling, the pedagogy developed at the folk high schools is characterized by horizontal relationships between teachers and students (Nordvall and Dahlstedt 2011).
} 
addressing the threat posed by the white merchant is a textbook example of the intended outcomes of the highly profiled joint Nordic development aid projects launched in the late 1960s to promote the construction of co-operatives in targeted parts of Africa (Passkesen 2010). In Sweden, the co-operative ideology was an essential part of the dominant national narrative that democracy and the welfare state had been created through a compromise between workers and peasants organizing themselves through state independent co-operatives (Millbourn 2008). After the Phantom has taught the peasants to club together to protect themselves and their economic interests, the storyline addresses the fact that co-operatives were perceived as a threat to capitalism, as they promote another economic system. Just as the private sector in Sweden sought to put consumer co-operatives out of business through boycotts and price reductions (Millbourn 2008), the white merchants drop their prices in order to lure the peasants back to their store. An enraged Trader Joe rebukes the peasants, explaining ferociously that this is merely a dirty business trick to bankrupt their co-operative store before raising the prices again. The last panel of the story shows smiling villagers, having finally listened to Trader Joe's advice, inside their own co-operative store full of food and equipment.

Although done with the best of intentions, the Phantom's actions in the name of solidarity are not immune to the criticism that Gayatri Spivak (2008) directs toward development aid programmes in the Third World. Despite the change in politics from the American version, the Phantom rekindles a colonialist position as he remains a guardian and teacher of the locals whose interests and needs he dictates in order to direct their actions toward an appropriate end. As seen in the story above, the Phantom assumes that the locals do not have the expertise and ability to develop models that allow them to fight the monopoly of the white merchants without his help. Help which, according to Spivak $(2008,15)$, often serves as a cover for the social Darwinism implicit in 'development', framed as 'the burden of the fittest' as the responsibility to educate the natives rests on the Phantom's broad shoulders. In line with colonialist representations, the Phantom is the superior helper of the passive and inadequate natives whose unreliability almost destroys the system that the masked hero puts in place to protect them: their lack of understanding of a co-operative in combination with their short sighted and unpredictable consumption patterns nearly bankrupt the store they have been given to own collectively.

Such colonial echoes in Sweden's championing of global solidarity are not limited to The Phantom: they have been uncovered in various foreign aid activities (Eriksson Baaz 2005), including the exportation of study circles (Wallin 2000), popular adult education (Nordvall and Dahlstedt 2011), and co-operatives (Paaskesen 2010). Offering a parallel to the Phantom comics, these studies uncover a larger contradictory discourse in which there is, on the one hand, a strong anticolonial impulse inherent in the efforts of Swedish foreign aid to break with the colonial heritage; on the other hand, colonialist representations are prevalent in the construction of differences and a hierarchical organization of invoked subjects. In all the studies listed above it is the Swedes, like the Phantom, who, albeit benevolently, sustain the privilege and power of possessing the knowledge that people in different parts of Africa require to challenge the structures of oppression and inequality under which they are living. Regardless of intent, this scholarship reveals that it is the Swedes who essentially define the conditions and set the framework for success and failure, based on specific 'Swedish' interpretations of how to run a study circle, a folk high school or, as in the case of the Phantom, a co-operative. 


\section{Colonial Rule, Swedish Exceptionalism}

What distinguishes The Phantom from the most prominent example of New Left ideology in comics of the period, Denny O'Neil and Neal Adams' Green Lantern/Green Arrow (1970), is that the hero in the former never undergoes growth. In the latter, the Green Lantern is portrayed as having a naïve faith in corporatist America and the possibilities for justice under capitalism. Accompanying the Green Arrow on a trip around the US becomes an eye-opening experience for the Green Lantern as he is confronted with social, racial and economic injustices of which he was previously unaware. Back home again, the Green Lantern's political compass points in another direction.

The Phantom, on the other hand, stands firm in his beliefs. In contrast to the Green Lantern and by extension his American readership, the Ghost Who Walks does not need any additional lectures on politics; his understanding of ethics and inequalities are unwavering - which, in turn, suggests that 'we', the Swedish readers, do not need to be reminded about what is morally 'correct' and humanitarian either. A possible explanation for these ideological differences is that at the time of writing, the US was suffering from what Costello $(2009,87)$ refers to as 'an erosion of national identity consensus'. After years of unifying against an external enemy - reflected in comics from Captain America punching Adolf Hitler to Iron Man's fight against Soviet spies - the tumultuous events of 1968, sparked by the war in Vietnam and the assassinations of Martin Luther King Jr. and Robert F. Kennedy, played a part in what Bruce Schulman (2001) refers to as the undoing of the post-war consensus leading to the political fragmentation of the 1970s.

By contrast, ideological consensus remained potent in Sweden. Although several scholars relate this to the dominance of the Social Democratic Party and their ability to formulate foreign aid policies accordingly (Linderborg 2001; Lödén 1999), the consistency in foreign policy is preeminently illustrated by the fact that the change of government to a conservative coalition (1976-82) did not produce any significant alterations (Odén 2013). In order to understand this phenomenon other academic commentators move away from party politics to speak more broadly about a discourse of 'Swedish exceptionalism' (Habel 2012; Hübinette and Lundström 2011; Schierup and Ålund 2011). Sweden, according to these scholars, presents itself as a radical utopia for equality and equity, allegedly less affected by postcolonial relations than other nations, by virtue of its welfare politics, and its democratic and egalitarian principles (Habel, 2012). Although Sweden admittedly took an active part in the imperial enterprise through, for instance, the possession of the slave fortress Carolusborg in Cabo Corso (modern-day Ghana) and the Caribbean island Saint Barthélemy (Aman 2016), the relative brevity of these colonial adventures has become, paradoxically, an important resource in the branding of Sweden as a humanitarian role model (Jonsson 2009). Katarina Schough (2008) suggests that the limited scope of this involvement has awarded Sweden a double moral advantage: as a participant in the colonial project, the Swede is self-evidently superior to the natives, while also morally superior to the colonizer whose expansive empires acquired through widespread violence they can easily condemn. This can be said to have contributed to an image of Swedish identity as tolerant, colourblind and nonracist (Bjereld and Demker 1995), while also adding credibility as Sweden was beginning to position itself as a leading anticolonial voice. All of these factors, as Allan Pred $(2000,6)$ contends, contributed to successfully launching Sweden 'as the world's capital of good intentions and civilized behaviour towards others.' 
The above offers a possible reason why the Phantom comes across as untouched by colonial and postcolonial social dynamics. Although he is a descendant of an English aristocratic family residing in a former British colony, the national 'adoption' of the Phantom as part of Sweden's self-image whitewashes both the character and his family line which runs parallel to the rule of the British Empire. This holds particularly true in issue 26/1970, 'The Water Test', ${ }^{12}$ when a former British general returns to Bangalla in the autumn of his life. During a car ride out of the capital, Morristown, the officer, General Williams, tells his daughter, Nora, unsentimental stories of his time serving in Bangalla ('We tried to introduce law and order and some civilization in their miserable country'). Invited to a principality in the north of Bangalla, the General is unaware of the tensions that his visit provokes among the locals who are still trying to heal the colonial wound. Discussing his visit, the Rajah (a possible nod to, and relic of, Falk's placement of Bangalla closer to India) ruling the principality and his First Minister have not forgotten the violence enacted upon them by the British under the General's command. However, while the Minister is plotting to have the general assassinated ('He should die! I can't forget what he has done to me and my people!'), the Rajah wants to avoid vengeance as he is aware of the continuing interdependency of Europe and the former colonies ('Let the past rest in the past. We're dependent on good international relationships - even with the former colonial power').

After the Phantom arrives in time to prevent General Williams from being killed, the Minister resorts to kidnaping Nora. He tells her the truth about her father ('They captured the city and we resorted to guerrilla warfare! For four years your father kept the city captured!'), and the devastating consequences his rule had on the local population as he confiscated all there was to eat in the principality to feed his soldiers ('People starved to death'). The Phantom, having overheard the conversation, confronts the General who defends his actions by claiming that he was only following orders. In response, the Minister screams out 'you're an unscrupulous murderer - a war criminal!' while throwing a punch at General Williams. Not taking sides, the Phantom launches a physical attack on the Minister and his men to disarm them before turning to the General for an uncommon verbal attack ('You're truly astoundingly stupid, General! These people hate your guts and you don't even realize why!').
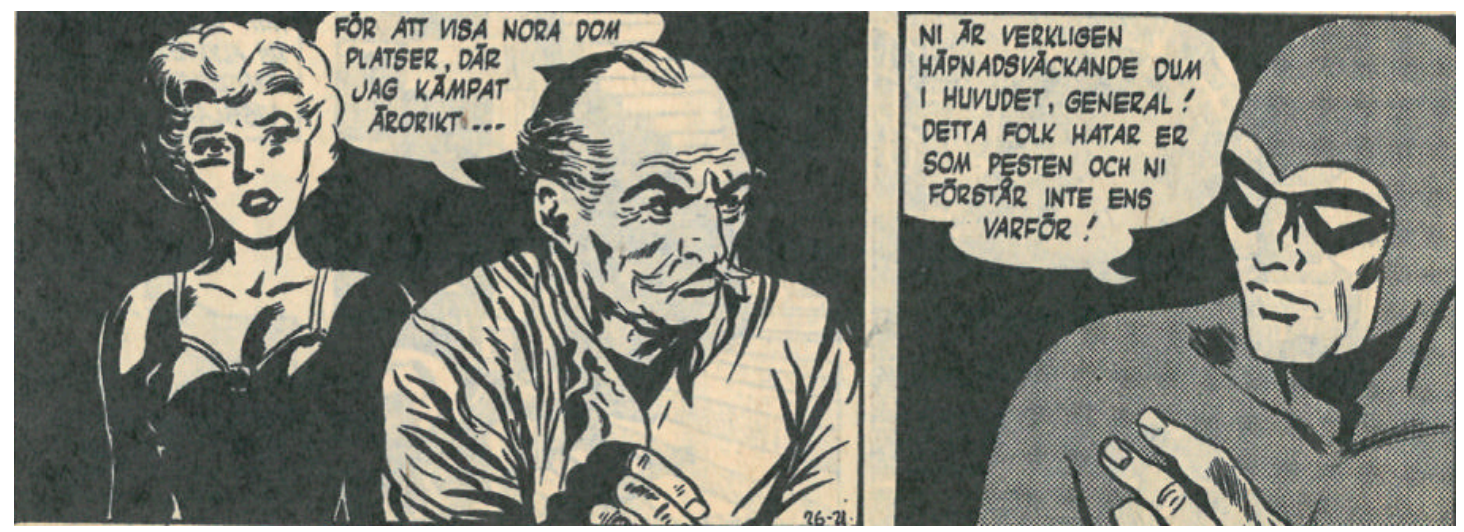

The Phantom rebukes General Williams who says that he wanted to show his daughter those places where he had fought gloriously. (C) King Features Syndicate Inc. / Distr. Bulls

\footnotetext{
${ }^{12}$ Fantomen, 26/1970, script: Janne Lundström, art: Bertil Wilhelmsson.
} 
Far from being merely words of frustration, there is more invested in the Phantom's emotional outburst. His loss of temper and raised voice serve as an important narrative device in the context of the roman à these. Instead of a subtle use of metaphor or analogy, the comic impatiently ensures a correct reception of its intended meaning through repetitive mentions of the blood on General Williams' hands as a participant in repellent imperial practices. For emphasis, the story even has the protagonist, otherwise known to have ice running through his veins, react emotionally on the reader's behalf. In this way a verbal attack comes across as a natural response to a representative of colonialism who is not only incapable of understanding the damage and suffering he has caused, but who also shows no signs of remorse, still convinced of the superiority and righteousness of the imperialists.

Loyal to the ground rules of the roman à thèse, the story thrives on ideological polarization as the General, filled with colonial nostalgia and mourning the loss of empire, encapsulates the colonial ideology: in rationalizing his mission as an attempt to introduce 'civilization', his statement alludes to the rhetoric employed to legitimize European imperialism, insofar as it claimed to consciously set out to modernize, develop, instruct, and civilize (Said 1994). Difference is turned into subordination as the colonial text, embodied by General Williams who suggests that the geopolitical space in question lacks 'civilization' as well as 'law and order', emphasizes the perceived shortcomings of the natives - their backwardness and ignorance - so that imperialism could be justified as a necessary, albeit sometimes unfortunate, step to supersede savagery (Mignolo 1999). In a manner reminiscent of Walter Benjamin's $(1969,258)$ famous dictum - 'There is no document of civilization which is not at the same time a document of barbarism' - the comic blurs the distinction between civilization and barbarism by uncovering the destructive logic often hidden underneath keywords such as 'modernization', 'development', and 'civilization', revealing the violence enacted upon colonized populations in their name (Aman 2017). This receives its fictional outlet in the Phantom's response when Nora asks how she is ever going to be able to thank him: 'By telling the truth about your people's warfare here!'.

The genitive construction is key in the above sentence. By referring to the British as 'your people' when referencing the past events of colonial rule, the Phantom, in spite of his Anglo-Saxon genes, instantly removes himself from any ties of kinship to Great Britain. Recognizing the Phantom's genealogy would spark ambiguity as it opens up a reading of the character as a colonial settler. For the Phantom to hint at kinship with Britain here, to speak of 'our country' or 'my ancestors' homeland' in place of 'your', would negatively impact the purity of his morals by addressing a family line that runs through Britain's period of imperial expansion. This is not to suggest that the historical background of the Phantom dynasty is kept a secret in the Swedish scripts. On the contrary, as previously pointed out by Gudmundsson (2015), historical adventures form a large part of the body of work of Team Fantomen, in which the connection to Britain is made explicit to such a degree that the Phantom dynasty plays a part in the mythology of King Arthur and the Knights of the Round Table. ${ }^{13}$ However, what I am suggesting is that the Swedish scripts avoid statements that connect the Phantom to the nationality of his ancestors when the emphasis is on condemning British colonial practices.

\footnotetext{
${ }^{13}$ E.g. Fantomen, 19/1975, script: Ulf Granberg \& Jaime Vallvé, art: Jaime Vallvé; Fantomen, 13/1981, script: Norman Worker, art: Jaime Vallvé.
} 
The reason for this becomes apparent in the light of the editor Granberg's (1990) observation that the readers, like himself, have always considered the Phantom a Swedish hero. In the same way as Sweden conceals its involvement in the slave trade in order to sustain a national self-image as beacon of human rights, social justice and antiracism (Jonsson 2005), making the Ghost Who Walks Swedish - the transformation from the Phantom to Fantomen - allows him to pass uncontaminated by the burden of colonial legacies. For a roman à thèse, this dimension is essential as it distinguishes between two clear ideological positions in awarding the Phantom moral superiority in relation to General Williams; the same moral superiority to the imperialist nations that Sweden grants itself. In line with Schough's (2008) analysis above, this moral advantage works in two directions: besides superiority to General Williams as an embodiment of the British Empire, all the locals, stretching from remote jungle villages up to the Presidential Palace in Morristown, are filled with awe before the Phantom. Although with less explicit racial undertones, European innate superiority over native people remains a powerful trope that reaffirms a hierarchy of racial difference in the Swedish scripts.

Furthermore, the resolution to the drama allows the Phantom to embody the neutrality that plays an important part in Sweden's positioning of itself as an international moral authority (Nilsson 1991). With Nora on her way back to Britain, her kidnapper stands trial for his crimes. Informed about what has happened, the Rajah sees no other option than to put his minister on death row where his life can only be spared if he wins a competition based on who can hold their breath longest under water. The Phantom decides to represent the minister and subsequently wins the competition, saving his life. When the Rajah asks why he did it and how he picked a side in this complicated conflict with historical roots, the Phantom responds that he was on both sides for the sake of the principality and Nora. Acting as a diplomat, an intermediary between arrogant colonizers and vengeful colonized subjects, the Phantom performs a role in foreign policy that, under the rule of the Social Democratic Party, became a Swedish hallmark during the Cold War (Ottosson 2003). From this viewpoint, the Phantom's actions conform to an ideal of Sweden; he embodies a national fantasy of resolving international conflicts with, as underlined by Palme (2006, 230), 'reason'. Palme then adds that in any attempt to combine peace with national liberation there must be 'moral values as the basis for action,' moral values that are here embodied in an American superhero residing in Africa but personifying Swedish ideals.

\section{Conclusion}

Throughout this essay, the argument that I have advanced is that the Phantom comic, in the hands of the Swedish-based scriptwriters of Team Fantomen, instils the masked hero with political doctrines reflected in Swedish foreign policy during the late 1960s and early 1970 s, particularly in relation to African aid. In line with the conventions of the roman à thèse, the Phantom is the authorized voice that through words and actions expresses an ideological conviction that resonates with Sweden's positioning of itself as an 'international moral authority' as the result of its assumption of the role of selfproclaimed representative of social democracy, welfare politics and neutrality. In short, the Phantom series is the subject of an ideological shift in which the masked hero moves away from the role of colonialist fantasy prevalent in the American scripts to take a firm political stance against slavery, racism, and other forms of postcolonial injustice in the Swedish-produced stories. Although superhero comics 
have been defined as a crucial resource for legitimizing states' foreign policy (Dittmer 2013), it must be pointed out that, as novelist Paul Bourget (2010) once stated in relation to ideology in fiction, whether a representation of the world is deemed 'inaccurate' and 'slanted', or conversely, 'correct' and 'truthful' is at the end of the day decided by the political leanings of the reader - in this case, the readers of the immensely popular comic à thèse that is The Phantom.

\section{References}

Aman, Robert. 2017. Decolonising Intercultural Education: Colonial Differences, the Geopolitics of Knowledge, and Inter-Epistemic Dialogue. London: Routledge.

Aman, Robert. 2016. "Swedish Colonialism, Exotic Africans and Romantic AntiCapitalism: Notes on the Comic Series Johan Vilde", Third Text, 30(1-2), 60-75.

Barker, Martin. 1989. Comics: ideology, power and the critics. Manchester: Manchester University Press.

Barthes, Roland. 1973. Mythologies. London: Paladin.

Barthes, Roland. 1977. Image, Music, Text. London: Fontana.

Benjamin, Walter. 1969. Illuminations. New York: Schocken.

Bourget, Paul. 2010. Pages de critique et de doctrine. Paris: Nabu Press.

Chamberlain, Muriel. 1999. Decolonization: the fall of the European empires. Oxford: Blackwell Publishers.

Costello, Matthew. 2009. Secret Identity Crisis. New York: Continuum.

Dahlstedt, Magnus and Nordvall, Henrik. 2011. "Paradoxes of Solidarity: Democracy and Colonial Legacies in Swedish Popular Education", Adult Education Quarterly, 61(3), 244- 261.

Bjereld, Ulf and Demker, Marie. 1995. Utrikespolitiken som slagfält. De svenska partierna och utrikesfrågorna. Stockholm: Nerenius \& Santérus förlag.

Dittmer, Jason. 2013. Captain America and the Nationalist Superhero. Philadelphia: Temple University Press.

Eco, Umberto. 1972. "The Myth of Superman”, Diacritics, 2, 14-22.

Eriksson Baaz, Maria. 2002. The white wo/man's burden in the age of partnership: a postcolonial reading of identity in development aid. Göteborg: Göteborg University Press.

Fanon, Frantz. 1966. The wretched of the earth. New York: Grove Press. 
Fredriksson, Gunnar. 2006. "Olof Palmes gärning”, In Olof Palme, Solidaritet utan gränser: Tal och texter i urval, 21-33, Stockholm: Atlas.

Friese, Kai. 1999. “White Skin, Black Mask”, Transition, 80, 4-17.

Gleijeses, Piero. 2005. "Scandinavia and the Liberation of Southern Africa", The International History Review, 27(2), 324-331.

Granberg, Ulf. 1990. Fantomen: Krönika över en vandrande vålnad. Stockholm: Semic.

Gudmundsson, David. 2015. "The Ghost Who Walks Goes North: Early Modern Sweden in the Phantom, 1987-2008", Scandinavian Journal of Comic Art, 2(1), 7-24.

Habel, Ylva. 2012. "Challenging Swedish exceptionalism? Teaching while Black", In Kassie Freeman and Ethan Johnson (eds.), Education in the Black Diaspora:

Perspectives, Challenges and Prospects, 99-122, London: Routledge.

Hardt, Michael and Negri, Antonio. 2000. Empire. Cambridge, Mass.: Harvard University Press.

Hobsbawm, Eric. 2011. How to change the world: Marx and Marxism, 1840-2011. London: Little, Brown.

Hübinette, Tobias and Lundström, Catrin. 2011. "Sweden after the Recent Election", NORA, 19(1), 42-52.

Jonsson, Stefan. 2005. Världen i vitögat: tre essäer om västerländsk kultur. Stockholm: Norstedt.

Jonsson, Stefan. 2009. Rapport från Sopornas planet: kritiska essäer. Stockholm: Norstedt.

Knutsson, Magnus. 2003. "Fantomens 70-tal”, Fantomen Krönika, 56(4), 96-97.

Lee Falk Memorial Bengali Explorers Club. Scandinavian Chapter. 2011. Lee Falk: Story teller, Stockholm: GML.

Linde, Göran. 2000. Det ska ni veta!: en introduktion till läroplansteori. Lund: Studentlitteratur.

Linderborg, Åsa. 2001. Socialdemokraterna skriver historia: historieskrivning som ideologisk maktresurs 1892-2000. Uppsala: Uppsala University Press.

Lödén, Hans. 1999. "För säkerhets skull”: ideologi och säkerhet i svensk aktiv utrikespolitik 1950-1975. Göteborg: Göteborg University Press.

McAllister, Matthew P, Sewell, Edward H, and Gordon, Ian (eds.). 2001. Comics \& ideology. New York: Peter Lang. 
Mbembe, Achille. 2001. On the Postcolony. Berkeley: University of California Press.

Mignolo, Walter. 1999. Local histories/global designs. Princeton, NJ: Princeton University Press.

Millbourn, Ingrid. 2008. "Kooperatismen - ett alternativ till kapitalism och socialdemokratai 1900- 1920”, Scandia: Tidskrift för historisk forskning, 2, 89-112.

Moore, Jesse. 2003. "The Education of the Green Lantern: Culture and Ideology", The Journal of American Culture 26(2), 263-278.

Nilsson, Ann-Sofie. 1991. Den moraliska stormakten: en studie av socialdemokratins internationella aktivism. Stockholm: Timbro.

Odén, Bertil. 2013. "Biståndspolitiken" in Lenne, Marja and Tarschys, Daniel (eds), Vad staten vill, mål och ambitioner $i$ svensk politik, 21-66, Örlinge: Gidlunds Förlag.

O’Neil, Denny and Adams, Neal. 1970. Green Lantern/Green Arrow. New York: DC Comics.

Ottosson, Sten. 2003. Svensk självbild under kalla kriget. Stockholm: Utrikespolitiska Institutet.

Paaskesen, Kristian Ravn. 2010. "A Bleak Chapter in Nordic Development Aid History?: the Nordic Co-operative Assistance Project in Tanzania", Scandinavian Journal of History, 35(4), 451-470.

Palmberg, Mai. 1987. Afrika i skolböckerna. Stockholm: Sida.

Palme, Olof. 2006. Solidaritet utan gränser: Tal och texter i urval, Stockholm: Atlas.

Peterson, Mark Allen. 2009. "What is the point of media anthropology?" Social Anthropology, 17(3), 340-342.

Pred, Allan. 2000. Even in Sweden. Berkeley: University of California Press.

Rodney, Walter. 1972. How Europe underdeveloped Africa. London: BogleL'Ouverture.

Said, Edward. 1994. Culture \& Imperialism. London: Vintage.

Schierup, Carl-Ulrik and Ålund, Alexandra. 2011. "The end of Swedish

exceptionalism? Citizenship, neoliberalism and the politics of exclusion", Race \& Class, 53(1), 45-64.

Schough, Katarina. 2008. Hyberboré. Föreställningen om Sveriges plats i världen. Stockholm: Carlsson.

Schulman, Bruce J. 2001. The seventies: the great shift in American culture, society, and politics. New York: Free Press. 
Sellström, Tor. 1999. Sweden and National Liberation in Southern Africa: Formation of a Popular Opinion (1950-1970), Uppsala: Uppsala Nordic Africa Institute.

Spivak, Gayatri. 2008. Other Asias. Oxford: Blackwell Publishing.

Suleiman, Susan. 1993. Authoritarian fictions: the ideological novel as a literary genre. Princeton, N.J.: Princeton University Press.

Wallerstein, Immanuel. 1974. "The rise and future demise of the of the worldcapitalist system: Concepts for comparative analysis", Comparative Studies in Society and History, 16, 387-415.

Wallin, Kerstin. 2000. Folkbildning på export? Stockholm: Stockholm University.

York, Chris and York, Rafiel. 2012. Comic books and the Cold War, 1946-1962:

essays on graphic treatment of communism, the code and social concerns. McFarland: Jefferson, N.C.

\section{NOTES ON CONTRIBUTOR}

Robert Aman is Lecturer in Education at the University of Glasgow. He primarily conducts research on ideology, national identity, and the politics of representation in comics. He has written and published a number of articles in journals such as Third Text and Cultural Studies. He is the author of Decolonising Intercultural Education: Colonial Differences, the Geopolitics of Knowledge, and Inter-Epistemic Dialogue (London, Routledge). 